Marquette University

\title{
e-Publications@Marquette
}

College of Nursing Faculty Research and

Publications

Nursing, College of

$11-2020$

\section{Using the Consolidated Framework for Implementation Research to Evaluate Clinical Trials: An Example from Multisite Nursing Research}

\author{
Linda L. Costa \\ University of Maryland - Baltimore \\ Kathleen L. Bobay \\ Loyola University Chicago \\ Ronda G. Hughes \\ University of South Carolina \\ Sarah J. Bahr \\ Marquette University \\ Danielle M. Siclovan \\ Froedtert Hospital
}

See next page for additional authors

Follow this and additional works at: https://epublications.marquette.edu/nursing_fac

Part of the Nursing Commons

\section{Recommended Citation}

Costa, Linda L.; Bobay, Kathleen L.; Hughes, Ronda G.; Bahr, Sarah J.; Siclovan, Danielle M.; Nuccio, Susan A.; and Weiss, Marianne E., "Using the Consolidated Framework for Implementation Research to Evaluate Clinical Trials: An Example from Multisite Nursing Research" (2020). College of Nursing Faculty Research and Publications. 812.

https://epublications.marquette.edu/nursing_fac/812 


\section{Authors}

Linda L. Costa, Kathleen L. Bobay, Ronda G. Hughes, Sarah J. Bahr, Danielle M. Siclovan, Susan A. Nuccio, and Marianne E. Weiss

This article is available at e-Publications@Marquette: https://epublications.marquette.edu/nursing_fac/812 
Marquette University

e-Publications@Marquette

\section{Nursing Faculty Research and Publications/College of Nursing}

This paper is NOT THE PUBLISHED VERSION; but the author's final, peer-reviewed manuscript. The published version may be accessed by following the link in the citation below.

Nursing Outlook, Vol. 68, No. 6 (November/December 2020): 769-783. DOI. This article is (C) Elsevier and permission has been granted for this version to appear in e-Publications@Marquette. Elsevier does not grant permission for this article to be further copied/distributed or hosted elsewhere without the express permission from Elsevier.

\section{Using the Consolidated Framework for Implementation Research to Evaluate Clinical Trials: An Example from Multisite Nursing Research}

\section{Linda L. Costa}

University of Maryland School of Nursing, Organizational Systems and Adult Health, Baltimore, MD Kathleen Bobay

School of Health Sciences and Public Health, Professor, Marcella Niehoff School of Nursing, Loyola University, Chicago, IL

Ronda Hughes

Center for Nursing Leadership, Director, Executive Doctorate of Nursing Practice, Associate Professor, University of South Carolina College of Nursing, Columbia, SC

Sarah J. Bahr

Marquette University College of Nursing, Milwaukee, WI

Danielle Siclovan

Risk Management, Froedtert and The Medical College of Wisconsin, Milwaukee, WI 


\section{Susan Nuccio}

Marquette University College of Nursing, Milwaukee, WI

\section{Marianne Weiss}

Marquette University College of Nursing, Milwaukee, WI

\section{Abstract}

\section{Background}

The Consolidated Framework for Implementation Research (CFIR) is a comprehensive guide for determining the factors that affect successful implementation of complex interventions embedded in real-time clinical practice.

\section{Purpose}

The study aim was to understand implementation constructs in a multi-site translational research study on readiness for hospital discharge that distinguished study sites with low versus high implementation fidelity.

\section{Methods}

In this descriptive study, site Principal Investigator interviews (from 8 highest and 8 lowest fidelity sites) were framed with questions from 20 relevant CFIR constructs. Analysis used CFIR rules and rating scale (+2 to -2 per site) and memos created in NVivo 11.

Findings

From a bimodal distribution of differences (1.5 and 5), 7 constructs distinguished high and low fidelity sites with $\geq 5$-point difference.

\section{Discussion}

CFIR provided a determinant framework for identifying elements of a study site's context that impact implementation fidelity and clinical research outcomes.

\section{Keywords}

Implementation science, fidelity, translational research

\section{Introduction}

Multisite research studies provide the opportunity for health systems to collaborate to better understand the impact of interventions across larger populations than within any one organization. Multiple organizations working together can aggregate research data to more rigorously assess the effect of the intervention on improving patient outcomes. These studies also provide an opportunity to explore the organizational contexts of the implementing sites, providing a window into the underpinnings that make some organizations successful with complex interventions while others fail to implement even core components of the research. The impact of the intervention on patient outcomes is influenced by myriad human, sociocultural, and organization factors referred to as context (Alexander \& Herald, 2012). Variations in organization structure, mission, resources, and staff support 
can facilitate or impede the delivery of new evidence-based practices. Knowledge about organizational context can aid researchers in developing implementation strategies that facilitate success. Key issues that need to be explored in evaluating context include readiness for change, the fit of complex multicomponent interventions, and fidelity to the intervention (Alexander \& Herald, 2012).

The Readiness Evaluation and Discharge Interventions (READI) study was an international, clusterrandomized, multi-site clinical trial that involved translation of prior evidence about nurse assessment and patient self-report of readiness for hospital discharge through integration into day-of-discharge nursing practices (Weiss et al., 2019). Clinical nurses assigned to the implementation units in 33 Magnet hospitals ( 1 implementation and 1 control unit per hospital, 31 US hospitals, 2 Saudi Arabia hospitals) were trained in the evidence on readiness for discharge assessment and study protocol procedures. Three sequential discharge readiness assessment protocols were required for the study in a year-long intervention. During Protocol 1, the discharging nurse assessed the patient for readiness; in Protocol 2, the patient completed a self-assessment of discharge readiness and then the discharging nurse completed a parallel assessment informed by the patient's responses and all other information about the patient known to the nurse; in Protocol 3, the discharging nurse was informed of a cut-off score for low readiness and was instructed to initiate actions to prevent readmission for all low scores. In all protocols, the nurses used their professional judgment to determine appropriate actions in response to their discharge readiness assessments. The study goal was to implement the READI protocols with all eligible patients on the implementation units to influence post discharge utilization. Previously published results for the READI study noted that the use of READI protocol 2 was associated with readmission reduction of nearly 2 percentage points in intent-to-treat analysis from highreadmission units $(\geq 11.3 \%)$ with a stronger effect (3 percentage points) for patients actually treatedper- protocol (Weiss et al., 2019).

Fidelity to the intervention was a concern during this study. Measuring the extent that the protocol was implemented as planned (fidelity) is an important component of protocol delivery and study outcomes. Identifying contextual elements of the research environment that affect fidelity produces a clearer picture of influencers on study outcomes (Hasson, 2010). For the READI study, standardized education for sites was provided through an internet platform with web conferencing and downloadable PowerPoint presentations. Each READI nurse researcher $(n=4)$ was responsible for a site visit to an assigned hospital (eight or nine hospitals per researcher). The visit purpose was to meet the site Principal Investigator (PI) and study team, participating clinical staff, nurse leaders, and Chief Nurse Officers (CNOs). In addition, because of the large deidentified dataset that each hospital was required to extract from their electronic health records, a meeting with information technology (IT) personnel was included during site visits when possible. During site visits, contextual variations were noted including site PI experience, leadership support, frontline nurse engagement, electronic health records implementation, and patient acuity.

READI researchers used site PI interview as an implementation evaluation method to capture descriptive information on the variations in structures and processes used by the site PIs and their site study teams to implement the READI study. The purpose of the PI interview was to describe contextual factors in the implementation of the READI study associated with high and low fidelity to the intervention protocols. Qualitative approaches such as interviews with key informants used in 
conjunction with quantitative methods provide an enhanced understanding of why evidence-based practices are successfully implemented in one setting and not as successfully in another (Albright, Gechter, \& Kempe, 2013). Interviewing site PIs as key informants provided qualitative data to enhance understanding of implementation fidelity rates.

\section{Methods}

\section{Design}

The study was designed as a descriptive comparison of implementation experiences at hospitals participating in the READI study, focusing on the contextual factors that distinguished sites with high fidelity (HF) versus low fidelity (LF) to the READI protocol. Sites submitted monthly patient tracking logs of eligible patients and intervention completion to the central study team. Fidelity rates were calculated based on the number of patients with completed READI protocols divided by the number of eligible patients on each implementation unit. To explore differences in implementation context between HF and LF sites, we selected the 8 sites with the highest fidelity and the 8 sites with the lowest fidelity (upper and lower quartiles of 33 participating sites) for inclusion in this study, in order to maximize the opportunity to identify the differences between HF and LF sites. The development of a semistructured guide for site PIs interviews was considered the best method to gain an understanding of site experiences with implementing the study.

\section{Interview Guide Development Process}

A determinant implementation evaluation framework, the Consolidated Framework for Implementation Research (CFIR), was selected to develop the site PI interview guide. Determinant frameworks describe domains that have been found to be influential on implementation by identifying barriers and enablers impacting implementation (Nilsen, 2015). The CFIR framework is a synthesis of multiple implementation theories that can be used for planning, formative, or summative evaluation of "what works where and why across multiple contexts" (Damschroder et al., 2009, p. 2). CFIR has been used in a wide variety of settings for studying operational aspects of implementation through the lens of the socioecological dynamics of changes at multiple levels (e.g., clinician, organizational) (Tabak et al. 2012) using qualitative, quantitative and mixed methods (Kirk et al., 2015). Health care settings have been the most common settings for use of the CFIR framework with research objectives focused on gaining an understanding of practitioners' experiences in innovation implementation (Kirk et al., 2015). Innovations included health care delivery and process re-design, health promotion and disease management (Hill et al. 2018; Kirk et al., 2015). CFIR was selected as the guiding framework for this post-implementation evaluation due to its direct applicability to health care settings, its structure that guides evaluation of implementation factors across organizational layers within the setting, and the availability of detailed interview questions that can be customized for the study.

The CFIR has 39 constructs organized across five domains: intervention characteristics, outer setting, inner setting, individual characteristics, and process. Damschroder and Lowery (2013) recommended researchers should select relevant domains and constructs for a particular study. CFIR questions related to all constructs were downloaded from the website, www.cfirguide.org. Four READI study investigators each separately identified their perceptions of relevant constructs and questions. Potential interview questions were revised based on construct definitions and specific components 
applicable to the READI study. Investigators then met in a face-to-face meeting to develop the final questions using a consensus approach. During this 8-hour meeting, final constructs were identified that were thought relevant to understanding study implementation. A total of 20 of the 39 CFIR constructs from 4 of the 5 CFIR domains were included in the interview guide: (a) In the intervention characteristics domain, we measured 6 constructs including intervention source, relative advantage, adaptability, complexity, design and packaging, and cost. (b) In the outer setting domain, we measured the needs and resources of the patient population served by the organization, including patient responses to being asked about discharge readiness. (c) The inner setting domain includes features of structural, political, and cultural contexts. The inner setting for the READI study was the implementation unit. The construct "structural factors" included changes in leadership during the READI study and unit study team membership and effectiveness. The construct "networks and communication" queried the meeting methods and frequency among study teams. Within the construct "implementation climate," relevant subconstructs included relative priority of the study within the organization's scope of work, organizational incentives and rewards, and the learning climate. Within the construct "readiness for implementation," relevant subconstructs included leadership engagement (site $\mathrm{PI}, \mathrm{CNO}$, nonnurse leaders) and access to knowledge and information. (d) The domain characteristics of individuals was not included because the intervention was at the unit level. (e) The effect of individuals within the implementation units was thought to be captured in the implementation process domain, which included four important leadership subconstructs (opinion leaders, formally appointed implementation leaders, champions, and key stakeholders). The final two constructs "executing" and "reflecting and evaluating" encouraged the site PI to reflect on implementation and consider how the organization will measure success of the READI study. CFIR construct definitions can be found at https://cfirguide.org/constructs/.

To finalize the interview guide format for logic in the flow of the interview conversation, questions were then grouped under eight topics including: Site PI role, READI decision process, READI effect on unit operations, reactions to READI, local study team, study implementation, clinical staff engagement, and life after READI.

\section{Data Collection}

Institutional Review Board approval was obtained from the IRB of record for the READI study, Marquette University. The University of Maryland provided nonhuman subject determination for this secondary data analysis. Online consent to participate in the interview was obtained from the site PIs. All site PIs agreed to participate in an interview. Interviews were conducted via Go-to-Meeting between March 2016 and January 2017. Each interview had two study team members, one who conducted the interview and another who recorded verbatim comments and summary notes during the interview. The audio portion of the interviews were recorded to be used as needed to clarify respondent comments. The investigators did not conduct interviews with PIs from their assigned sites. Interviews ranged in length from 45 minutes to 1 hour

\section{Data Analysis}

Completed interviews guides were formatted and entered in NVivo 11. Deidentified sites were randomly assigned among three READI nurse researchers, two raters per site. A codebook with definitions of CFIR constructs was used to define each construct. From the interviews, memos 
representing the notes and verbatim comments made by respondents during the interviews were created in NVivo 11. Several constructs used more than one question to uncover site experience related to the construct. The comments from these multiple questions were treated as a group to create a rating score for the construct. Guided by recommendations from Damschroder and Lowery (2013), the READI investigators evaluated constructs based on CFIR Rating Rules for: valence $(+/-/ X / 0)$ and strength $(1,2)$. The valence rating was determined by the influence the coded data had on the implementation process, i.e. contextual factors that facilitate $(+)$ or hinder (-) implementation. If comments regarding constructs were mixed and could not be classified as positive or negative a mixed $(X)$ rating can be used. If comments were neutral, or had no bearing on implementation, a (0) rating was applied. The strength component of a rating ( 1 to 2 ) is determined by factors including strength of language and use of concrete examples. Scoring +2 indicates the construct had a strong positive influence on implementation. Scoring +1 means the construct had a weak to moderate influence. Negative scoring of -2 indicates strong negative influence and -1 indicates weak to moderate negative influence (www.cfirguide.org).

We used a consensus approach where researchers met via web conference to review rating variances. The third researcher who had not rated the site facilitated consensus discussions. We had no difficulty reaching consensus nor comparing constructs across cases. We created a rating score for each site's ratings for the 20 individual constructs. The score was the sum of the 2-rater scores for each of the sites: there was a summed score for the low $(n=8)$ and high $(n=8)$ fidelity sites. The possible range of summed construct rating scores was from -16 to +16 . After completing the scoring, we found a bimodal distribution of difference scores between HF and LF with modes at 1.5 and 5.0. Therefore, we considered a difference $\geq 5$ points as indicating a construct distinguishing HF and LF sites.

\section{Findings}

Mean fidelity for the READI study was $70.8 \%$ and the median fidelity across all sites was $76 \%$ (Weiss et al., 2019); however, there was wide variation among sites. Fidelity rates for the 8 LF sites ranged from $29 \%$ to $60 \%$. Fidelity rates for the $8 \mathrm{HF}$ sites ranged from $92 \%$ to $99 \%$. Study sites had the following characteristics: LF sites included 1 academic medical center and 7 community hospitals; HF sites included 4 academic medical centers and 4 community hospitals. Hospital bed size was 180 to 650 for LF sites and 220 to more than 1500 for HF sites. LF study units had 21 to 48 beds and HF units had 24 to 36 beds; LF units included 6 medical (for telemetry/mixed acuity cardiac, general medicine, pulmonary, stroke, diabetes patients), 1 surgical, and 1 mixed medical surgical units and HF sites included 4 medical (telemetry/ mixed acuity cardiac, general medicine, pulmonary) units; 24 to 95 nurses were trained in the READI intervention protocols in LF units and 27 to 63 nurses in HF units, Unit readmission rates at baseline ranged from $2 \%$ to $16 \%$ for LF units and 9 to $17 \%$ for HF units. Compared to LF sites, HF sites had a lower proportion of site PIs with doctoral degrees (25\% vs 50\%), more PIs with at least 6 years in their current role (67\% vs 33\%), and similar prior experience as a PI (62\%).

Of the 20 CFIR constructs embedded in the site PI interview, the differences in rating scores for LF versus HF sites was $\geq 5$ points for seven of the constructs. Figure 1 illustrates these seven constructs, all of which were in the intervention characteristics domain and the inner setting domain. Distinguishing constructs included: Adaptability and complexity in the intervention characteristics domain, and structural characteristics (study team), relative priority, organizational incentives and rewards (site PI 
and staff), leadership engagement (Chief Nurse Officer), and access to knowledge and information (READI team and training information) in the inner setting domain. Most scores for the 7 distinguishing constructs were in the positive range, except for complexity and relative priority of the study where LF sites scored in the negative range and for adaptability, HF sites scores were negative. Figure 1 plots the construct summed scores distinguishing high and low fidelity sites.

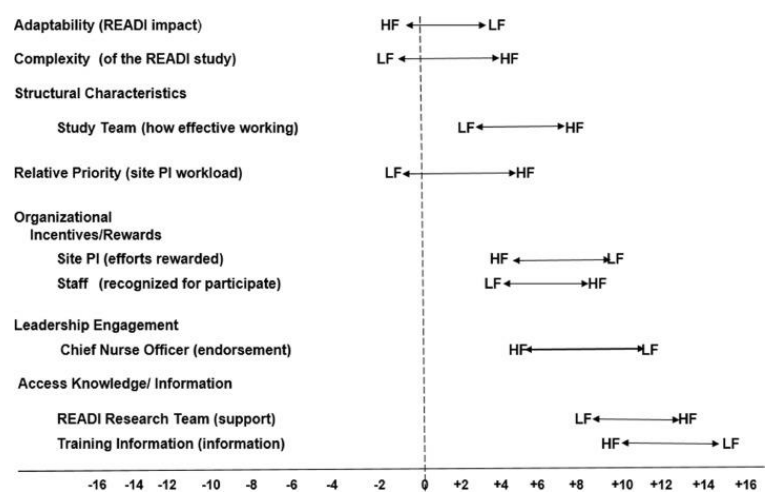

Figure 1. Summed constructs distinguishing high [HF] $(n=8)$ and low fidelity [LF] $(n=8)$ Sites by $\geq 5$ points*

*Each construct rated +2 to -2 per site then summed across the 8 high versus 8 low fidelity sites.

Several constructs had modest ( $>1$ but $<5$ point) differences between LF and HF sites. These constructs included intervention characteristics: (a) design quality and packaging - both LF and HF rated as positive with customizable PowerPoints and webinars helpful, though rated with higher positive scores in LF sites; and (b) intervention costs - rated positive in both LF and HF sites; however, several site had "no impact" ratings (0). In LF sites, costs were often not tracked; however, time for staff training was allocated in the unit budget. For HF sites, costs were cited by PIs as part of doing research. In the outer setting domain, patient response to being asked about discharge readiness was positive in both LF and $\mathrm{HF}$ sites although higher for LF sites. In the inner setting, scores for engagement of non-nurse leaders were positive for both HF and LF sites but lower for LF, with comments indicating limited communication with non-nurse leaders because the study involved one unit in the hospital. In the process domain, four categories of leadership had high positive scores for both LF and HF sites, including opinion leaders (individuals in the organization have influence on attitudes of their colleagues); formally appointed implementation leaders (either the site PI or research coordinator); champions (individuals who dedicate themselves to driving the intervention); and key stakeholders (individuals in the organization directly impacted by the intervention)

Six constructs were scored $\leq 1$-point difference between LF and HF sites. In the intervention characteristics domain, both HF and LF sites had high positive scores for the externally developed READI study supported by a nationally recognized accrediting body (American Nurses Credentialing Center). The inner setting constructs included: (a) structural characteristics, specifically changes in leadership during the READI study (b) networks and communication, (c) learning climate, and (d) leadership (site PI) engagement. Inner setting scores were positive for these constructs in both LF and HF sites; however, structural/leadership changes had the lowest scores, suggesting that leadership changes may have interfered with the effectiveness of leadership as a facilitator of study implementation. 
Table 1 has construct scores and examples of case memos for LF and HF sites.

Table 1. CFIR Constructs and Interview Questions, Rating Scores, and Example Case Memos

\begin{tabular}{|c|c|c|c|c|}
\hline CFIR constructs & READI Study Interview Questions & $\begin{array}{l}\text { Rating } \\
\text { Scores } ¥ \text { LF } \\
\text { Sites/HF } \\
\text { Sites }\end{array}$ & $\begin{array}{l}\text { Example Case Memos - Low } \\
\text { Fidelity (LF) Sites }\end{array}$ & $\begin{array}{l}\text { Example Case Memos - High } \\
\text { Fidelity (HF) Sites }\end{array}$ \\
\hline \multicolumn{5}{|l|}{$\begin{array}{l}\text { I. INTERVENTION } \\
\text { CHARACTERISTICS } \\
\text { DOMAIN }\end{array}$} \\
\hline $\begin{array}{l}\text { 1.Intervention } \\
\text { source }\end{array}$ & $\begin{array}{l}\text { What are the main factors } \\
\text { influencing to participate in } \\
\text { READI? }\end{array}$ & $+11.5 /+10.5$ & $\begin{array}{l}\text { Application to Magnet was the } \\
\text { driving force. The study had a } \\
\text { ready-made protocol and } \\
\text { design. }+2\end{array}$ & $\begin{array}{l}\text { PI requested the organization } \\
\text { to support the project. Benefits } \\
\text { include improving length of } \\
\text { stay (LOS) and potential gaps in } \\
\text { care. }+2\end{array}$ \\
\hline $\begin{array}{l}\text { 2. Relative } \\
\text { advantage }\end{array}$ & $\begin{array}{l}\text { Has the discharge process on the } \\
\text { unit changed since the READI } \\
\text { study? How is the READI study } \\
\text { similar or conflicting with other } \\
\text { discharge programs? } \\
\text { Are there nondischarge initiatives } \\
\text { or activities related to hospital } \\
\text { policies, practices, priorities that } \\
\text { could impact the study? }\end{array}$ & $-0.5 /+3.0$ & $\begin{array}{l}\text { Prior to the study, we did not } \\
\text { have an overarching discharge } \\
\text { program on this unit. Many of } \\
\text { our issues with discharge have } \\
\text { to do with timing of discharge. } \\
\text { Focus is on timeliness...nurses } \\
\text { calling physicians to get orders } \\
\text { for patients they were told are } \\
\text { leaving. }-1\end{array}$ & $\begin{array}{l}\text { There is a major push for } \\
\text { progression of care and LOS. } \\
\text { Partnering for excellence and } \\
\text { rounding going on throughout } \\
\text { the study. The staff know LOS } \\
\text { very well; they speak to the } \\
\text { MDs about it. }+2\end{array}$ \\
\hline 3.Adaptability & $\begin{array}{l}\text { What new discharge initiatives or } \\
\text { activities are or have happened } \\
\text { that might impact on the READI } \\
\text { results? Is the READI study } \\
\text { conflicting with any programs? }\end{array}$ & $+4.5 /-0.5^{*}$ & $\begin{array}{l}\text { Transition team had } \\
\text { developed a checklist and a } \\
\text { robust discharge phone call. } \\
\text { The checklist has been going } \\
\text { on during the study and the } \\
\text { phone call was always there } \\
\text { but was adjusted a little bit. } \\
\text { All seemed to work well } \\
\text { together. }+1.5\end{array}$ & $\begin{array}{l}\text { Phase } 3 \text { of the study there } \\
\text { were new consults/wound care } \\
\text { and may have extended the } \\
\text { hospitalization or delayed } \\
\text { discharge. There was a big } \\
\text { push to move patients. }-1.5\end{array}$ \\
\hline
\end{tabular}




\begin{tabular}{|c|c|c|c|c|}
\hline 4.Complexity & $\begin{array}{l}\text { How easy or complex is the READI } \\
\text { study for you as a PI to } \\
\text { coordinate? Which parts are } \\
\text { easier, which are most difficult? }\end{array}$ & $-1.0 /+4.5^{*}$ & $\begin{array}{l}\text { The data collection looked } \\
\text { basic. We had the survey and } \\
\text { filled it out. As the progression } \\
\text { of the study continued, the } \\
\text { data retrieval was the complex } \\
\text { part of it. The IRB was just a } \\
\text { tedious process. Hard wiring } \\
\text { the nurses to fill out the } \\
\text { papers was difficult. We spent } \\
\text { a lot of time on the front end } \\
\text { for the IT people to cooperate. } \\
\text { It was a political and } \\
\text { organizational challenge. }-2 X\end{array}$ & $\begin{array}{l}\text { Easy to coordinate. Resources } \\
\text { on website and contact with } \\
\text { READI researcher was most } \\
\text { helpful. }+2\end{array}$ \\
\hline $\begin{array}{l}\text { 5.Design Quality } \\
\text { and Packaging }\end{array}$ & $\begin{array}{l}\text { Have you found the study website } \\
\text { helpful? Which materials on the } \\
\text { website were most helpful? Was } \\
\text { the website effective to support } \\
\text { the materials needed for } \\
\text { implementation? Was the logistics } \\
\text { planning worksheet helpful? }\end{array}$ & $+7.5 /+6.0$ & $\begin{array}{l}\text { The customizable training } \\
\text { Power Points were great and } \\
\text { the recorded webinars. } \\
\text { Logistic worksheets were } \\
\text { helpful for how the study } \\
\text { worked but thinking back we } \\
\text { would have liked a more } \\
\text { detailed follow up. }+2\end{array}$ & $\begin{array}{l}\text { Data was helpful straight } \\
\text { forward, could get resources, } \\
\text { user friendly. It was helpful } \\
\text { especially for the staff. }+2\end{array}$ \\
\hline 6.Cost & $\begin{array}{l}\text { Are you tracking costs of the } \\
\text { implementation? How and what } \\
\text { are you tracking? }\end{array}$ & $+5.5 /+2$ & $\begin{array}{l}\text { Training for the first phase, we } \\
\text { were able to allocate the staff } \\
\text { time. Second and third phase } \\
\text { were shorter so done on their } \\
\text { time. }+1.5\end{array}$ & $\begin{array}{l}\text { No, it is in our job description } \\
\text { to do research. } 0\end{array}$ \\
\hline \multicolumn{5}{|l|}{$\begin{array}{l}\text { II. OUTER SETTING } \\
\text { DOMAIN }\end{array}$} \\
\hline $\begin{array}{l}\text { 7.Patient Needs } \\
\text { and Resources }\end{array}$ & $\begin{array}{l}\text { How are the patients responding } \\
\text { to being asked about discharge } \\
\text { readiness? What if any feedback } \\
\text { have you gotten from patients } \\
\text { regarding their experiences? } \\
\text { What impact to date do you think }\end{array}$ & $+12.5 /+8$ & $\begin{array}{l}\text { Very few refused. } \\
\text { The only issue that came up } \\
\text { was that if patients only had } \\
\text { an hour before leaving and } \\
\text { were given paperwork then } \\
\text { they tended to not fill it out. }\end{array}$ & $\begin{array}{l}\text { Patients did not mind. Most } \\
\text { filled it out. } \\
\text { Patient experience (similar to } \\
\text { HCAHPS) has improved almost } \\
20 \% \text {. Study resulted in } \\
\text { increased education for }\end{array}$ \\
\hline
\end{tabular}




\begin{tabular}{|c|c|c|c|c|}
\hline & $\begin{array}{l}\text { the READI study is having care } \\
\text { processes and patient outcomes? }\end{array}$ & & $\begin{array}{l}\text { Needed to get to them earlier } \\
\text { in the four-hour window. }+1.5\end{array}$ & $\begin{array}{l}\text { patients and more patient } \\
\text { involvement. Nurses are now } \\
\text { considering the entire nursing } \\
\text { care process for areas to } \\
\text { improve. }+2\end{array}$ \\
\hline \multicolumn{5}{|l|}{$\begin{array}{l}\text { III. INNER SETTING } \\
\text { DOMAIN }\end{array}$} \\
\hline \multirow[t]{2}{*}{$\begin{array}{l}\text { 8.Structural } \\
\text { characteristics }\end{array}$} & $\begin{array}{l}\text { Changes in leadership } \\
\text { Have there been changes to } \\
\text { hospital leadership (CNO), unit } \\
\text { leadership, or the site PI since the } \\
\text { start of the READI study? How did } \\
\text { any of these changes impact the } \\
\text { study implementation? }\end{array}$ & $+2.5 /+2.0$ & $\begin{array}{l}\text { PI retired and position was not } \\
\text { replaced. Assistant manager } \\
\text { position removed. }-1\end{array}$ & $\begin{array}{l}\text { CNO changed into a COO role. } \\
\text { The new CNO was not } \\
\text { involved. Nursing Informatics } \\
\text { person retired. The new Senior } \\
\text { Director was the previous unit } \\
\text { director and that helped the } \\
\text { study quite a bit. }-1.5\end{array}$ \\
\hline & $\begin{array}{l}\text { Study team } \\
\text { What is the } \\
\text { composition/structure of the } \\
\text { study team at your hospitals (is it } \\
\text { just you? How effectively is the } \\
\text { team working? }\end{array}$ & $+4.0 /+9.0 *$ & $\begin{array}{l}\text { At first, the team was site } \mathrm{PI} \text {, } \\
\text { educator, data and quality } \\
\text { people but ended up with only } \\
\text { educator (new site } \mathrm{PI} \text { ). }-1\end{array}$ & $\begin{array}{l}\text { Site } \mathrm{PI}, \mathrm{CNO} \text { and Nursing } \\
\text { research council chair, nurse } \\
\text { manager, nurse lead, and } \\
\text { educator. Watched training } \\
\text { webinars together. }+1.5\end{array}$ \\
\hline $\begin{array}{l}\text { 9. Networks and } \\
\text { Communication }\end{array}$ & $\begin{array}{l}\text { How often does your study team } \\
\text { meet formally and informally? }\end{array}$ & $+10.5 /+10.5$ & $\begin{array}{l}\text { Met regularly at the start of } \\
\text { each phase of the study. After } \\
\text { the beginning of each phase, } \\
\text { held "just in time" meetings. } \\
\text { The group was functional, and } \\
\text { the study leaders were } \\
\text { physically located nearby so it } \\
\text { was helpful. Consistency of } \\
\text { team members helped. }+2\end{array}$ & $\begin{array}{l}\text { Regularly scheduled meetings } \\
\text { lead to better communication. } \\
\text { Monthly reports to various } \\
\text { groups. Also discussed at } \\
\text { implementation staff meetings. } \\
\text { Everyone facilitated. }+2\end{array}$ \\
\hline $\begin{array}{l}\text { Implementation } \\
\text { Climate: } \\
\text { 10. Relative priority }\end{array}$ & $\begin{array}{l}\text { How has being site PI for the } \\
\text { READI study affected your } \\
\text { personal workload? }\end{array}$ & $-1.0 /+5.5^{*}$ & $\begin{array}{l}\text { It increased, that is why I } \\
\text { needed an extra person to } \\
\text { help. It did not occur to me at } \\
\text { the time all the other time } \\
\text { commitments. It was }\end{array}$ & $\begin{array}{l}\text { It has increased the workload. } \\
\text { It was never thought of as a } \\
\text { bad thing, but I had to go to } \\
\text { the unit every day and more } \\
\text { than previously. It was also an }\end{array}$ \\
\hline
\end{tabular}




\begin{tabular}{|c|c|c|c|c|}
\hline & & & $\begin{array}{l}\text { overwhelming as part of my } \\
\text { workload to add the READI } \\
\text { study. }-2\end{array}$ & $\begin{array}{l}\text { opportunity to participate in a } \\
\text { research study on that unit }+1\end{array}$ \\
\hline \multirow[t]{2}{*}{$\begin{array}{l}\text { 11.Organizational } \\
\text { incentives and } \\
\text { rewards }\end{array}$} & $\begin{array}{l}\text { Site PI } \\
\text { To what extent are your efforts as } \\
\text { site PI being recognized by } \\
\text { leadership in your organization? } \\
\text { What are the benefits to you, in } \\
\text { terms of recognition within your } \\
\text { organization, of being a site PI? }\end{array}$ & $+10.5 /+4.5^{*}$ & $\begin{array}{l}\text { Magnet resubmission is due at } \\
\text { the end of the year, so } \\
\text { leadership is very aware. The } \\
\text { transition team (two hospital } \\
\text { systems merged) are aware } \\
\text { and include information in the } \\
\text { forum. }+2\end{array}$ & $\begin{array}{l}\text { Seen as any other task that she } \\
\text { is responsible for planning. No } \\
\text { extra benefit. - } 1\end{array}$ \\
\hline & $\begin{array}{l}\text { Unit staff } \\
\text { How are staff being incentivized } \\
\text { to participate in the READI study? } \\
\text { How are staff being rewarded for } \\
\text { participation in the READI study? }\end{array}$ & $+3.5 /+8.5^{*}$ & $\begin{array}{l}\text { Staff not being incentivized. } \\
\text { Positive feedback to keep } \\
\text { momentum going. Fidelity } \\
\text { graph. }+1\end{array}$ & $\begin{array}{l}\text { Staff like new things, being part } \\
\text { of big research. Certificates for } \\
\text { each education session for } \\
\text { performance appraisal reviews. } \\
+2\end{array}$ \\
\hline $\begin{array}{l}\text { 12.Learning } \\
\text { climate }\end{array}$ & $\begin{array}{l}\text { What was the level of receptively } \\
\text { of the implementation unit to the } \\
\text { READI study? }\end{array}$ & $+7 /+7.5$ & $\begin{array}{l}\text { In order to get the nurses to } \\
\text { see the impact of what they } \\
\text { were doing, when their } \\
\text { compliance was high the } \\
\text { patient satisfaction was high, } \\
\text { so their efforts were paying } \\
\text { off. }+1.5\end{array}$ & $\begin{array}{l}\text { Reinforced that they were } \\
\text { going to see the results, that } \\
\text { this was an international study. } \\
\text { I talked with the champions, } \\
\text { that this was part of their } \\
\text { clinical ladder. }+2\end{array}$ \\
\hline $\begin{array}{l}\text { Readiness for } \\
\text { Implementation } \\
\text { 13.Leadership } \\
\text { engagement }\end{array}$ & $\begin{array}{l}\text { Site PI } \\
\text { What critical attributes do you see } \\
\text { as necessary for a site PI in the } \\
\text { READI study? }\end{array}$ & $+11 /+11$ & $\begin{array}{l}\text { Basic understanding of } \\
\text { research } \\
\text { Understanding of } \\
\text { implementation processes, } \\
\text { IRB processes, and how to } \\
\text { obtain reports } \\
\text { The ability to collaborate, } \\
\text { mentor, and reorganize work. } \\
\text { Prioritize, teach and mentor, } \\
\text { have big picture, enthusiasm. } \\
+2\end{array}$ & $\begin{array}{l}\text { Commitment to the study, no } \\
\text { matter what you have on your } \\
\text { plate, I have many units as an } \\
\text { educator and CNS. } \\
\text { Organizational skills and } \\
\text { collaboration skills, } \\
\text { communication. Established } \\
\text { relationship with the staff, } \\
\text { important to have a strong link } \\
\text { rather than having someone } \\
\text { coming from the outside. }+2\end{array}$ \\
\hline
\end{tabular}




\begin{tabular}{|c|c|c|c|c|}
\hline & $\begin{array}{l}\text { Chief Nursing Officer } \\
\text { Has your CNO made visible } \\
\text { his/her endorsement of the READI } \\
\text { study? If so, how. }\end{array}$ & $+10 /+5^{*}$ & $\begin{array}{l}\text { Leadership meetings always } \\
\text { have an update added on. } \\
\text { CNO constantly following up } \\
\text { with } \mathrm{PI} \text {, manager, and staff. }+2\end{array}$ & $\begin{array}{l}\text { Higher leadership is in a flux, } \\
\text { interim CNO aware but not a } \\
\text { lot. Previous CNO handed us } \\
\text { the ball. }-1\end{array}$ \\
\hline & $\begin{array}{l}\text { Non-nurse leaders } \\
\text { What is the level of awareness of } \\
\text { the READI study among non- } \\
\text { nursing leaders in the } \\
\text { organization? }\end{array}$ & $+3.0 /+6.0$ & $\begin{array}{l}\text { We are pretty nursing } \\
\text { focused, but I would say it } \\
\text { really does not touch ancillary } \\
\text { workers. Informatics has a } \\
\text { good understanding. } \\
\text { Hospitalists are semi-aware. } \\
+1\end{array}$ & $\begin{array}{l}\text { We talked about it with the } \\
\text { medical directors; their } \\
\text { knowledge at the local level is } \\
\text { present. This is a large } \\
\text { organization; it is hard to } \\
\text { communicate throughout the } \\
\text { organization. We are waiting } \\
\text { for the results to take the next } \\
\text { steps. }+1\end{array}$ \\
\hline \multirow[t]{2}{*}{$\begin{array}{l}\text { 14.Access to } \\
\text { knowledge and } \\
\text { information }\end{array}$} & $\begin{array}{l}\text { READI team } \\
\text { Have you received sufficient } \\
\text { information and support from the } \\
\text { research team? }\end{array}$ & $+8.5 /+13.5^{*}$ & $\begin{array}{l}\text { Would have liked more detail } \\
\text { and a timelier response. A grid } \\
\text { or table would have been } \\
\text { more helpful because the } \\
\text { requirements would have } \\
\text { been more delineated. }-1\end{array}$ & $\begin{array}{l}\text { Had good support, liked the } \\
\text { webinars, never had any } \\
\text { problems, whatever questions } \\
\text { we had they were answered. } \\
\text { Most important to have the } \\
\text { face to face contact. }+2\end{array}$ \\
\hline & $\begin{array}{l}\text { Training information } \\
\text { How effective were the training } \\
\text { webinars and the training } \\
\text { materials for clinical staff } \\
\text { education about the READI } \\
\text { protocol? }\end{array}$ & $+15.0 /+9.5^{*}$ & $\begin{array}{l}\text { The webinar made me slow } \\
\text { down and really hear } \\
\text { everything. I think this really } \\
\text { helped me. Training times } \\
\text { gave us enough time to } \\
\text { prepare and if we needed } \\
\text { more information, we could } \\
\text { always go back to material. }+2\end{array}$ & $\begin{array}{l}\text { PowerPoint slides for each } \\
\text { phase helpful. Phase } 1 \text { and } \\
\text { planning webinars were the } \\
\text { most helpful. Phase } 2 \& 3 \text { not as } \\
\text { much new info but helpful to } \\
\text { know we were on right track. } \\
+1.5\end{array}$ \\
\hline \multicolumn{5}{|l|}{ V. Process Domain } \\
\hline $\begin{array}{l}\text { Engaging } \\
\text { 15.Opinion leaders }\end{array}$ & $\begin{array}{l}\text { What are influential individuals on } \\
\text { the implementation unit saying } \\
\text { about READI? Who are the } \\
\text { influencers (position)? }\end{array}$ & $+13 /+12.5$ & $\begin{array}{l}\text { Mainly positive comments. } \\
\text { Case Manager-often asking } \\
\text { "any data yet?" and has been } \\
\text { engaged } \\
\text { RNs will ask if there is } \\
\text { anything they need to be }\end{array}$ & $\begin{array}{l}\text { The unit leadership sent } \\
\text { weekly quality reports and } \\
\text { included the study as to how it } \\
\text { was going. } \\
\text { I see the unit several times }\end{array}$ \\
\hline
\end{tabular}




\begin{tabular}{|c|c|c|c|c|}
\hline & & & $\begin{array}{l}\text { doing differently. } \\
\text { The manager is involved and } \\
\text { tells the PI the nurses like the } \\
\text { study. } \\
\text { PI walking around unit. }+2\end{array}$ & $\begin{array}{l}\text { every week and elicited } \\
\text { feedback. }+2\end{array}$ \\
\hline $\begin{array}{l}\text { 16. Formally } \\
\text { appointed } \\
\text { Implement-ation } \\
\text { leaders }\end{array}$ & $\begin{array}{l}\text { How did you become site PI for } \\
\text { the READI study? }\end{array}$ & $+12 /+9.5$ & $\begin{array}{l}\text { I received an email from } \\
\text { [study sponsor] announcing } \\
\text { the study, I took it to my } \\
\text { counterpart to see if any of } \\
\text { the sister hospitals would be } \\
\text { interested, we were the only } \\
\text { ones that could do it; took to } \\
\text { the IRB and it was accepted. } \\
+2\end{array}$ & $\begin{array}{l}\text { I was approached by the nurse } \\
\text { research director about the } \\
\text { possibility of joining the study. } \\
\text { It originated with the CNO. It } \\
\text { was much needed. I have } \\
\text { always had an interest in } \\
\text { research. }+2\end{array}$ \\
\hline 17. Champions & $\begin{array}{l}\text { Did you identify unit champions } \\
\text { on the implementation units? } \\
\text { How did you determine who } \\
\text { would be unit champions? When } \\
\text { during the implementation } \\
\text { planning process did you engage } \\
\text { the champions? What has been } \\
\text { the role of unit champions? }\end{array}$ & $+11.5 /+10$ & $\begin{array}{l}\text { Unit champions were } \\
\text { identified for their leadership } \\
\text { qualities displayed at council } \\
\text { meetings and other shared } \\
\text { governance venues. They } \\
\text { were responsible, showed } \\
\text { interest, and appreciation for } \\
\text { the importance of the study. } \\
+2\end{array}$ & $\begin{array}{l}\text { We looked at their level of } \\
\text { interest with research... We } \\
\text { tried to mix it up with new staff } \\
\text { and others who were on the } \\
\text { unit about } 10 \text { years. And we } \\
\text { asked for volunteers, if not } \\
\text { they were selected. }+2\end{array}$ \\
\hline $\begin{array}{l}\text { 18. Key } \\
\text { stakeholders }\end{array}$ & $\begin{array}{l}\text { How are you communicating with } \\
\text { nursing staff about progress of } \\
\text { the READI study? What } \\
\text { materials/modes/venues do you } \\
\text { use? }\end{array}$ & $+12.5 /+14$ & $\begin{array}{l}\text { Progress was shared at unit } \\
\text { meetings and through } \\
\text { postings in the back/break } \\
\text { rooms. The data were also } \\
\text { shared at research council and } \\
\text { shared in newsletters to reach } \\
\text { the broader staff levels. }+2\end{array}$ & $\begin{array}{l}\text { Regularly attended unit } \\
\text { meetings, nursing research } \\
\text { newsletters, staff RN talked } \\
\text { about experience, staff nurse } \\
\text { presentation/poster }+2\end{array}$ \\
\hline 19.Executing & $\begin{array}{l}\text { How active is unit leadership in } \\
\text { encouraging participation in the } \\
\text { READI study? How active are staff }\end{array}$ & $+8 /+11$ & $\begin{array}{l}\text { It has been an expectation. } \\
\text { The focus is on improving } \\
\text { patient care and it is a way to } \\
\text { get nurses on board. }\end{array}$ & $\begin{array}{l}\text { Unit leader encouraged staff to } \\
\text { participate. The clinical leads } \\
\text { with supervision of the director } \\
\text { were giving the }\end{array}$ \\
\hline
\end{tabular}




\begin{tabular}{|c|c|c|c|c|}
\hline & $\begin{array}{l}\text { in encouraging each other to } \\
\text { participate? }\end{array}$ & & $\begin{array}{l}\text { Sometimes an extra thing to } \\
\text { do, but part of patient care. }+1\end{array}$ & $\begin{array}{l}\text { encouragement. These were } \\
\text { the interim leaders. They never } \\
\text { let it be on the back seat. }+2\end{array}$ \\
\hline $\begin{array}{l}\text { 20. Reflecting and } \\
\text { evaluating }\end{array}$ & $\begin{array}{l}\text { How will your organization } \\
\text { determine if the study is } \\
\text { successful? What is the metric of } \\
\text { success? }\end{array}$ & $+12 /+12.5$ & $\begin{array}{l}\text { We are in the process of } \\
\text { reinstituting the assessment. I } \\
\text { didn't want to end it because } \\
\text { it was the right thing to do. } \\
\text { But the longer we didn't do } \\
\text { the assessment the lower the } \\
\text { [satisfaction] scores were } \\
\text { from the patients. They } \\
\text { decided to adopt the patient } \\
\text { piece as most valuable and } \\
\text { felt that was the piece that } \\
\text { was missing from our practice. } \\
\text { So we created it electronically. } \\
\text { Now the night shift would } \\
\text { begin the assessment; the day } \\
\text { shift would complete and } \\
\text { wrap it up. +2 }\end{array}$ & $\begin{array}{l}\text { We will wait for results of the } \\
\text { study, but more important to } \\
\text { us is whether the staff felt it } \\
\text { was important to them. We } \\
\text { want to know if they gained } \\
\text { new knowledge. I think it is } \\
\text { important to know their } \\
\text { perception and find out if they } \\
\text { think it improved patient care. } \\
+2\end{array}$ \\
\hline
\end{tabular}

$\mathrm{X}$ - Denotes mixed comments within the rating.

$*$ Constructs distinguishing high and low fidelity sites by $\geq \mathbf{5}$.

$¥$ Rating scores calculated by summing the 2-rater scores for LF and HF sites; maximum score is 16 . 


\section{Discussion}

The CFIR was valuable for identifying distinguishing constructs when comparing the intervention implementation in LF and HF sites. The high overall level of fidelity achieved in this study demonstrated the commitment of the nurses from the study units given the size and scope of what nurses were asked to do along with the many competing demands of patient care over a long study period. However, since fidelity variance was evident across sites, the opportunity to study site characteristics within the lowest and highest quartiles of fidelity can inform future multisite research of facilitators and barriers within intervention implementation that can affect study fidelity.

Seven constructs were considered to distinguish LF versus HF sites. In the intervention characteristics domain, complexity and adaptability were the distinguishing constructs. Intervention complexity has been found to influence implementation fidelity (Hanson, 2010). In LF sites, site PIs identified barriers including the daily requirements for documenting protocol completion rates and data retrieval from complex hospital information systems as burdensome. In comparison, site PIs in HF sites found teamwork and taking responsibility for understanding data sources part of their role, which facilitated discussions with IT staff about variables needed from administrative and financial databases. We learned that a clearer understanding of the scope of research components (assessments and interventions) and data requirements, particularly for electronic data, was needed for sites to determine readiness to implement the study protocol. The difference in adaptability scores was primarily affected by two sites, one HF and one LF. In the LF site, the composition of the patient population changed from inpatient to primarily observation patients during the study period, significantly increasing discharged patient volume. For the HF site, several initiatives were in process to achieve early discharge. When Protocol 3 that required an action for low readiness scores was implemented, it created a delayed discharge for some patients.

In the inner setting domain, five constructs distinguished LF and HF sites: structural characteristics, relative priority, organizational incentives/rewards, leadership engagement, and access to knowledge/information. Structural characteristics evaluated the social complexity of the study, evident in how many people and roles were involved with READI implementation. Study teams on HF units had diverse membership including managers, clinical nurses, case managers, and often nursing informatics or an IT representative/liaison. LF sites tended to have fewer team members to start and lost members over time. Relative priority, the perception of the importance of implementation within the organization, was evident in the site PI's priority within their workload and their personal capacity. This was a strongly distinguishing construct with a negative score in LF sites. The READI team specified that an additional 0.2 FTE would be required for the study. However, the personal capacity of site PIs to introduce a complex study was not built into the estimated qualifications or workload and could have affected implementation fidelity. The construct incentives and rewards, with positive scores, was a facilitator for this study; however, for LF organizations, the recognition for the site PI was scored higher than for staff. This could reflect a reward for managing the READI study which was viewed as complex. The HF sites used broader team membership overall to implement the study and this translated to recognizing and rewarding all staff who participated, including celebrations as the study progressed through three phases. The site PIs at HF sites often reported that leading research was part of their role responsibilities within their organizations. 
Leadership engagement of the CNO was a important factor in sites' readiness for implementation. LF sites had higher positive scores than HF sites, largely due to CNO turnover in HF sites. The CNO made a 3-year financial commitment at the beginning of READI study to fund the organization's enrollment in this pay-to-participate study (Hickey, Koithan, Unruh, \& Lundmark, 2014). All participating sites were Magnet hospitals, and LF sites more frequently indicated the importance of participating in the study to meet the New Knowledge component of the requirements for Magnet redesignation from American Nurses Credentialing Center (which can be found at https://www.nursingworld.org/organizationalprograms/magnet/magnet-model/rom).

For the construct access to knowledge and information, both HF and LF sites reported positive scores. HF site PIs reported greater support from the READI research team than LF sites which reported greater satisfaction with the training materials and methods. Face-to-face and individual contact with the research team was valued by all sites, as were the train-the-trainer webinars and customizable PowerPoint training materials for trainings for each phase of the study. Accessing hospital databases for data retrieval was particularly challenging. Several site PIs had limited knowledge of data found in hospital databases and how to identify and access the appropriate IT department staff to obtain data. During site visits, it was evident some sites would have benefited from extra support in setting up data collection tables, identifying where to find required electronic variables, and interacting with the IRB. Site PIs from HF organizations contacted the READI study team often to clarify and problem solve particularly related to data acquisition, whereas LF site PIs found accessing website information helpful. While the electronic data acquisition process should not have affected on-unit fidelity in applying the READI intervention, the differences between the experiences of site PIs at HF and LF sites may have contributed to their overall pattern of performance of study tasks.

Table 2 presents the constructs distinguishing LF and HF sites with barriers encountered and recommended strategies identified by the READI research team to mitigate them. Some of these barriers and solutions have also been identified in other reports of multisite study implementation. For example, in a multi-site implementation of an intervention to improve hazardous drug exposure prevention, Friese et al., (2017) identified infrastructure for nursing-led research and IT changes as challenges in multi-site study management. Successful strategies included web conference, site-based champions, site visits by the investigator, and central preparation of study documents. In a multisite implementation study of a nurse-led Parent Educational Discharge Support Strategies intervention for children newly diagnosed with cancer (Patton, Montgomery, Coyne, Arthur, \& Hockenberry, 2020), barriers to multisite research included study dissemination and promotion, hospital leadership engagement and communication, education and mentoring, nursing time for study activities, and study team coordination with local sites. Successful strategies included informational calls with site leadership and regular progress reports, frequent scheduled communication with sites, engaging site PIs in providing guidance for operational issues, and concise intervention materials that could easily integrate into routine workflow. The challenges and strategies for the READI study were remarkably similar to these example studies.

Table 2. Distinguishing Constructs from Analysis of High and Low Fidelity Sites: Potential Barriers and Recommendations 


\begin{tabular}{|c|c|c|}
\hline $\begin{array}{l}\text { I.INTERVENTION } \\
\text { CHARACTERISTICS }\end{array}$ & & \\
\hline Adaptability & $\begin{array}{l}\text { - Decrease in unit fidelity over } \\
\text { the course of the study } \\
\text { - Change in unit's patient } \\
\text { population during the study. } \\
\text { - Conflict in priorities for the } \\
\text { study vs. other hospital } \\
\text { specific initiatives to address } \\
\text { hospital discharge } \\
\text { - The study protocols may } \\
\text { have prolonged hospital stay }\end{array}$ & $\begin{array}{l}\text { - Use unit champions to determine sources } \\
\text { of decreased fidelity and facilitate greater } \\
\text { fidelity as needed. Explore options for timing } \\
\text { of study procedures and how protocol can } \\
\text { be integrated with usual care practices } \\
\text { - Determine if new patient populations } \\
\text { qualify for the study } \\
\text { - Interdisciplinary teams can facilitate } \\
\text { communication across initiatives focused on } \\
\text { the same outcome. } \\
\text { - Locally, use intentional communication } \\
\text { strategies to get protocol information into } \\
\text { the hands of clinical leaders to reduce the } \\
\text { impact of conflicting messages and keep the } \\
\text { focus on the patient for best care practice. }\end{array}$ \\
\hline Complexity & $\begin{array}{l}\text { - Daily data collection was } \\
\text { difficult for a single individual } \\
\text { to oversee. } \\
\text { - Unfamiliarity with hospital } \\
\text { databases caused a stressful } \\
\text { situation for site PIs }\end{array}$ & $\begin{array}{l}\text { - The level of FTE support should be } \\
\text { determined by each site. Pre-study } \\
\text { estimates may not considered applicable } \\
\text { across all sites as resources are variable in } \\
\text { amount and flexibility. } \\
\text { - Recognize that many PIs will need } \\
\text { assistance in identifying and connecting with } \\
\text { IT resources in their organization and many } \\
\text { are unfamiliar with data language, structure, } \\
\text { and configuration. } \\
\text { - Include IT specialist on the study team. } \\
\text { - Initiate early joint training with site PIs and } \\
\text { IT specialist. }\end{array}$ \\
\hline \multicolumn{3}{|l|}{ III. INNER SETTING } \\
\hline $\begin{array}{l}\text { Structural } \\
\text { characteristics } \\
\text { Study team }\end{array}$ & $\begin{array}{l}\text { - Limited roles included in } \\
\text { teams } \\
\text { - Infrequent team meetings } \\
\text { as study progressed }\end{array}$ & $\begin{array}{l}\text { - Identify key team roles for the study based } \\
\text { on the intervention. Engage leadership and } \\
\text { practicing nurses in co-managing the } \\
\text { project. } \\
\text { - Identify how much time is needed at the } \\
\text { beginning and negotiate time with senior } \\
\text { leaders. } \\
\text { - Set up regular meetings less frequently as } \\
\text { study progresses however maintain face-to- } \\
\text { face meeting to keep team intact and } \\
\text { informed. }\end{array}$ \\
\hline Relative priority & $\begin{array}{l}\text { - Multiple obligations for site } \\
\text { PIs in addition to READI. }\end{array}$ & $\begin{array}{l}\text { - Link READI to high priority organizational } \\
\text { initiatives such as maintaining Magnet }\end{array}$ \\
\hline
\end{tabular}




\begin{tabular}{|c|c|c|}
\hline & $\begin{array}{l}\text { - Non-nurse leaders may not } \\
\text { be informed of study and } \\
\text { importance to organization. }\end{array}$ & $\begin{array}{l}\text { status. } \\
\text { - Integrate the study into organizational } \\
\text { strategic plan. } \\
\text { - Highlight components of READI that may } \\
\text { address gaps in existing clinical programs } \\
\text { and initiatives. }\end{array}$ \\
\hline \multicolumn{3}{|l|}{$\begin{array}{l}\text { Organizational } \\
\text { incentives and } \\
\text { rewards }\end{array}$} \\
\hline Site PI & $\begin{array}{l}\text { - Recognition of the workload } \\
\text { of the site PI may not be } \\
\text { evident due to wide span of } \\
\text { responsibility in the } \\
\text { organization. }\end{array}$ & $\begin{array}{l}\text { - Actively communicate project data to } \\
\text { senior administrators. Share difficulties in } \\
\text { enrolling eligible patients due to staff time } \\
\text { constraints with workload. }\end{array}$ \\
\hline Clinical nurses & $\begin{array}{l}\text { - Clinical staff turnover rate } \\
\text { could affect study integrity. } \\
\text { Additional work at discharge } \\
\text { could be viewed as negative } \\
\text { due to added time. }\end{array}$ & $\begin{array}{l}\text { - Recognize staff and share unit data } \\
\text { frequently during study. Include in staff } \\
\text { meetings: highlight success stories, track } \\
\text { progress }\end{array}$ \\
\hline $\begin{array}{l}\text { Leadership } \\
\text { engagement (CNO) }\end{array}$ & $\begin{array}{l}\text { - Executive leaders may not } \\
\text { be aware of study } \\
\text { commitments, financially and } \\
\text { clinically. } \\
\text { - Leaders may not provide } \\
\text { material support for the study } \\
\text { if new to the organization }\end{array}$ & $\begin{array}{l}\text { - Present a business case for additional } \\
\text { allocation of staff time for training and } \\
\text { orientation of new staff. } \\
\text { - PI and team members keep CNO apprised } \\
\text { of study needs and successes. Maintain two- } \\
\text { way communication. }\end{array}$ \\
\hline \multicolumn{3}{|l|}{$\begin{array}{l}\text { Access to } \\
\text { knowledge and } \\
\text { information }\end{array}$} \\
\hline READI team & $\begin{array}{l}\text { - Site PI turnover in several } \\
\text { institutions }\end{array}$ & $\begin{array}{l}\text { - Provide face-to-face conferencing for new } \\
\text { Pls. Consider additional site visits if difficulty } \\
\text { in meeting study requirements. }\end{array}$ \\
\hline $\begin{array}{l}\text { Training } \\
\text { information }\end{array}$ & $\begin{array}{l}\text { - Information available on the } \\
\text { website. Some found it } \\
\text { difficult to navigate the files }\end{array}$ & $\begin{array}{l}\text { - Provide a roadmap for the site showing } \\
\text { beginning and phase's related files. } \\
\text { - Planned face-to-face videoconferencing } \\
\text { for review and practice accessing documents } \\
\text { and files. }\end{array}$ \\
\hline
\end{tabular}

The remaining 13 of the 20 CFIR constructs were not substantially different for LF and HF sites. Overall, the highest positive scores were obtained for the following constructs: intervention source; design quality and packaging; patient needs and resources; leadership engagement; engaging opinion leaders, formally appointed implementation leaders, champions, and key stakeholders; and reflecting/evaluating study results. These scores point to the common elements of the implementation that were rated as successfully contributing to implementation success. Research has identified leadership at all levels of the organization including nurse executives, managers and champions has a 
strong positive influence on positive work environments (Boamah, Laschinger, Wong, \& Clarke, 2018; Miech, et al. 2018; Pearson, 2020).

A few concepts were rated by both HF and LF sites as low positive or negative, suggesting areas for attention for study implementation and for planning future multi-site studies: complexity, relative priority and changes in leadership. Leadership changes at all levels in the organization occurred in many institutions during the READI study. Changes in leadership not only of senior managers but also middle managers (service line chiefs) and direct supervisors can aid or hinder implementation (Weiner et al., 2012).

The CFIR guidance on questions for each domain supported the development of the site PI interview guide for analysis of construct impact ratings. Implementation research occurs in real world settings distinguished by complexity and context (Landsverk, et al. 2012). We used the CFIR-based interview guide to help translate what we were told by key informants into evidence of implementation facilitators and barriers. We learned valuable information about each construct's impact on study fidelity. Analyzing 20 constructs using a valence and strength score allowed us to review each construct to see if there was uneven influence across sites. Although the CFIR with 5 domains and many constructs appears complex, using the tools for interview development based on the domains and constructs, the rating rules, and the literature reports of researchers' experience with CFIR provided on the website (www.cfirguide.org) created a path to follow.

\section{Limitations}

There are several limitations to the study. We interviewed site PIs as key informants. Therefore, their experiences constructed our understanding of the implementation processes. In aggregating their experiences, we reduced the individual unique experiences of our sites to quantitatively distinguish between the highest and lowest fidelity sites. We did not include the range of implementation experiences of sites with average study fidelity. The CFIR includes a total of 39 constructs. Nineteen constructs were not included due to limited relevance to the READI study but perhaps could have provided further insight; we constructed the interview guide to access key concepts and to respect the time burden to respondents in completing the interview. The READI questions were developed based on the construct definition as interpreted by the study team.

The interview and analysis were conducted by the nurse researchers who developed and managed the study. While we excluded ourselves from interviewing or conducting primary reviews of the interview responses of sites for which we each provided direct oversight and assistance during the study, our biases may have influenced interpretation of the findings particularly when disagreements occurred between primary reviewers.

\section{Recommendations for Future Research}

In planning future multisite studies, explication of implementation context will facilitate successful implementation of intervention protocols. While not applied for study planning or formative evaluation in the READI study, this framework would be valuable for designing proactive and corrective strategies to promote study fidelity. Strongly distinguishing constructs, complexity and relative priority in the organization work had negative scores in the LF sites. These constructs should be explored in depth before introducing new research to an organization system. 
The CFIR was useful as a guide for summative evaluation of implementation of the READI study. In multi-site studies, adaptation of the intervention to the local operational context while assuring that the core elements of the intervention protocol are the same across sites is essential for successful implementation and outcome measurement. Site leadership, communication among team members and the research team, organizational incentives and rewards were influential for site PIs and unit staff. Access to knowledge and information about the study and engaging leaders in several roles promoted HF. Study complexity, relative priority, and changes in leadership were associated with low fidelity. Connecting READI study fidelity data with analysis of context from site PI interviews increased the breadth of our understanding of individual site strengths and challenges in doing research in health systems.

\section{Acknowledgment}

Support for this study was provided by Pi Chapter, Sigma Theta Tau, International.

\section{References}

Albright, Gechter and Kempe, 2013. K. Albright, K. Gechter, A. Kempe. Importance of mixed methods in pragmatic trials and dissemination and implementation research. Academic Pediatrics, 13 (5) (2013), pp. 400-407, 10.1016/j.acap.2013.06.010

Alexander and Hearld, 2012. J.A. Alexander, L.R. Hearld. Methods and metrics challenges of deliverysystem research. Implementation Science, 7 (1) (2012), pp. 1-11, 10.1186/1748-5908-7-15

Boamah, Laschinger, Wong and Clarke, 2018. S.A Boamah, H.K. Laschinger, C. Wong, S. Clarke. Effect of transformational leadership on job satisfaction and patient safety outcomes. Nurs Outlook, 66 (2018), pp. 180-189, 10.1016/j.outlook.2017.10.004

Damschroder et al., 2009.

L.J. Damschroder, D.C. Aron, R.E. Keith, S.R. Kirsh, J.A. Alexander, J.C. Lowery. Fostering implementation of health services research findings into practice: A consolidated framework for advancing implementation science. Implementation Science, 4 (1) (2009), pp. 1$15,10.1186 / 1748-5908-4-50$

Damschroder and Lowery, 2013. L.J. Damschroder, J.C. Lowery. Evaluation of a large-scale weight management program using the consolidated framework for implementation research (CFIR). Implementation Science, 8 (1) (2013), pp. 1-17, 10.1186/1748-5908-8-51

Friese et al., 2017. C.R. Friese, K. MendelsohnVictor, P. Ginex, C.C. McMahon, A.J. Fauer, M.C. McCullagh. Lessons learned from a practicebased, multi-site intervention study with nurse participants. Journal of Nursing Scholarship, 49 (2) (2017), pp. 194-201, 10.1111/jnu.12279

Hasson, 2010. H. Hasson. Systematic evaluation of implementation fidelity of complex interventions in health and social care. Implementation Science, 5 (1) (2010), pp. 1-9, 10.1186/1748-5908-567

Hickey, Koithan, Unruh and Lundmark, 2014. J Hickey, M. Koithan, L. Unruh, V. Lundmark. Funding big research with small money. Journal of Nursing Administration, 44 (2014), pp. 309-

312, 10.1097/NNA.0000000000000072

Hill et al., 2018. J.N. Hill, S.M. Locatelli, B.G. Bokhour, G.M. Fix, J. Solomon, N. Mueller, S.L. LaVela. Evaluating broad-scale system change using the Consolidated Framework for Implementation Research: challenges and strategies to overcome them. BMC research notes, 11 (1) (2018), p. 560, 10.1186/s13104-018-3650-9 
Kirk, Kelley and Yankey, 2015. M.A. Kirk, C. Kelley, N. Yankey, A.B. Sarah, A Brenton, D Laura. A systematic review of the use of the Consolidated Framework for Implementation Research. Implementation Sci, 11 (2015), p. 72, 10.1186/s13012-016-0437-z

Landsverk et al., 2012.

J. Landsverk, C. Brown, P. Chamberlain, L. Palinkas, M. Ogihara, S. Czaja, ..., S.M. Horwitz.

Design and analysis in dissemination and implementation Research.

R.C. Brownson, G.A. Colditz, E.K. Proctor (Eds.), Dissemination and Implementation Research in Health: Translating Science to Practice, Oxford University Press, Oxford New York (2012), pp. $225-260$

Miech et al., 2018. E.J. Miech, N.A. Rattray, M.E. Flanagan, L. Damschroder, A.A. Schmid, T.M. Damush. Inside help: An integrative review of champions in healthcare-related implementation. SAGE Open Medicine, 6 (2018), Article 205031211877326, 10.1177/2050312118773261

Nilsen, 2015. P. Nilsen. Making sense of implementation theories, models and frameworks. Implementation Science, 10 (2015), pp. 50-53, 10.1186/s13012-015-0242-0

Patton et al., 2020. L. Patton, K. Montgomery, K. Coyne, M. Arthur, M. Hockenberry. Promoting direct care nurse engagement in research in magnet hospitals. JONA The Journal of Nursing Administration, 50 (5) (2020), pp. 287-292, 10.1097/NNA.0000000000000885

Pearson, 2020. M.M. Pearson. Transformational leadership principles and tactics for the nurse executive to shift nursing culture. JONA, 50 (3) (2020), pp. 142151, 10.1097/NNA.0000000000000858

Tabak, Khoong, Chambers and Brownson, 2012.

R.G. Tabak, E.C. Khoong, D.A. Chambers, R.C. Brownson. Bridging research and practice: models for dissemination and implementation research. American journal of preventive medicine, 43 (3) (2012), pp. 337-350, 10.1016/j.amepre.2012.05.024 Blinded for Review, 2019

Weiner, Haynes-Maslow, Kahwati, Kinsinger, \& Campbell, 2012. B.J. Weiner, L. HaynesMaslow, L.C. Kahwati, L.S. Kinsinger, M.K. Campbell. Implementing the MOVE! weightmanagement program in the Veterans Health Administration, 2007-2010: a qualitative study. Preventing chronic disease, 9 (2012), p. E16

Weiss et al., 2019. M. Weiss, O. Yakusheva, K. Bobay, L. Costa, R. Hughes, ..., J. Bang. Effect of implementing discharge readiness assessment on return to hospital in adult medical-surgical units on 30-day return to hospital: The READI randomized clinical trial. JAMA Network Open, 2 (1) (2019), p. e187387, 10.1001/jamanetworkopen.2018.7387 